Article

\title{
Navigating Online Language Teaching in Uncertain Times: Challenges and Strategies of EFL Educators in Creating a Sustainable Technology-Mediated Language Learning Environment
}

\author{
Leejin Choi ${ }^{1}$ (D) and Sunjoo Chung ${ }^{2, *(D)}$ \\ 1 Department of English Education, Hongik University, 94 Wausan-ro, Sangsu-dong, Mapo-gu, \\ Seoul 04066, Korea; choileejin@hongik.ac.kr \\ 2 Department of English Language and Literature, Gachon University, 1342 Seongnamdaero, Sujeong-gu, \\ Seongnam-si 13120, Gyeonggi-do, Korea \\ * Correspondence: sjchung@gachon.ac.kr
}

Citation: Choi, L.; Chung, S. Navigating Online Language Teaching in Uncertain Times: Challenges and Strategies of EFL Educators in Creating a Sustainable Technology-Mediated Language Learning Environment. Sustainability 2021, 13, 7664. https://doi.org/ $10.3390 /$ su13147664

Academic Editors:

Xuesong (Andy) Gao and

Mairin Hennebry-Leung

Received: 24 May 2021

Accepted: 7 July 2021

Published: 9 July 2021

Publisher's Note: MDPI stays neutral with regard to jurisdictional claims in published maps and institutional affiliations.

Copyright: (C) 2021 by the authors Licensee MDPI, Basel, Switzerland. This article is an open access article distributed under the terms and conditions of the Creative Commons Attribution (CC BY) license (https:// creativecommons.org/licenses/by/ $4.0 /)$.

\begin{abstract}
With the spread of COVID-19 worldwide, teaching and learning have occurred remotely and on digital platforms. An abrupt transition to online education, however, has posited unprecedented challenges for educators, who have been forced to adjust to remote learning with little to no time to prepare. Focusing on the case of an English language program in South Korea, this case study examines the challenges and strategies that were emerging in the crisis-prompted online language learning and teaching context. In particular, this case study focuses on investigating what types of strategies English as-a foreign language (EFL) instructors with little prior experience teaching online used to create a sustainable and authentic technology-mediated language learning environment, and how they motivated language learners to actively participate in sustainable language development and use. Findings provide educators and administrators who have little to no experience teaching online with practical suggestions and ideas to consider. They can use these concepts to adapt their lesson plans to online platforms and design and deliver high-quality lessons that ensure students feel connected to their learning process and have sustainable language learning experiences.
\end{abstract}

Keywords: English as a foreign language; sustainable learning; remote learning; teacher development; higher education

\section{Introduction}

With the spread of COVID-19 worldwide, teaching and learning have occurred remotely and on digital platforms. Many universities and school systems around the world switched to emergency remote learning to maintain instructional continuity in the face of the COVID-19 pandemic (Bozkurt and Sharma [1]; OECD [2]). An abrupt transition to online education, however, has posited unprecedented challenges for educators, who have been forced to adjust to remote learning with little to no time to prepare. Transitioning to an online learning environment can be particularly challenging for language educators whose main goal is to help learners develop their target language proficiency by encouraging meaningful and authentic interaction among learners and providing adequate feedback (González-Lloret [3]; Lomicka [4]). As the COVID-19 pandemic continues, many organizations and governments around the world provide language teachers and practitioners with instructional materials and resources for online teaching. Even though these resources and support could enable language educators to navigate through these uncertain times, it is necessary to take a look at the needs and experiences of language educators in order to further our understanding of the challenges they face and potential practical solutions at their disposal for creating sustainable technology-mediated language learning and teaching in times of crisis. 
Focusing on the case of an English language program in Seoul Metropolitan University in South Korea, this qualitative case study examines the challenges and strategies that were emerging in the crisis-prompted online language learning and teaching context. In particular, this case study focuses on investigating what types of strategies English as a foreign language (EFL) instructors with little prior experience teaching online used to create a sustainable and authentic technology-mediated language learning environment, and how they motivated language learners to actively participate in sustainable language development and use. Findings provide educators and administrators who have little to no experience teaching online with practical suggestions and ideas to consider. They can use these concepts to adapt their lesson plans to online platforms and design and deliver high-quality lessons that ensure students feel connected to their learning process and have sustainable language learning experiences.

\section{Literature Review}

With the advancement of information technology, remote language learning has increasingly been seen as an effective way to provide learners with more interactive and collaborative language learning environments. Effective online language learning and teaching involves a set of skills and knowledge different from those that have been used in traditional face-to-face teaching environments (see Baran et al. [5] for further discussion). Teaching online, thus, can be particularly challenging for educators who have little experience designing or delivering material via an online classroom because they tend to "introduce a new activity into existing institutions with established roles" (Natrielle [6]; p. 1890). In addition, online language teaching can present language teachers and students with various challenges, including limited online platforms that allow students to engage in authentic language interaction, difficulty in monitoring individual students' progress and work, and a lack of overall student motivation to actively participate in virtual interaction (e.g., Hampel and Stickler [7]; Lamy and Hampel [8]; Russell and Murphy-Judy [9]; and Sun [10]).

In comparing online learning and traditional face-to-face learning, recent studies point out the importance of a transformed teacher role and professional development in online classroom settings. They emphasize that it is important for language educators and practitioners to reconceptualize their approach to language teaching and learning, reimagine their role in promoting and facilitating learners' meaningful interaction, and transform their teaching practice to meet the specific needs of learners in online language learning and teaching contexts. Recently, the sudden shift from face-to-face teaching to online teaching in higher education due to the COVID-19 pandemic has required language teaching professionals to apply technology-mediated, sustainable innovations to reframe teaching practices. Technology-mediated, sustainable teaching promotes the consideration of specific teaching contexts and student needs and expectations to encourage the development of creative technology-enhanced teaching design solutions based on autonomous, teacher-driven innovations and collaboration (Bennett et al. [11]). As suggested by recent studies, the following are the key features of an effective online language educators who can successfully enhance their students' sustainable language development and use:

1. Language educators need to look for alternative ways to engage learners through virtual communication (Berge [12]; and Hampel and Stickler [7]);

2. Language educators need to support learners' autonomy during online language teaching and learning (Reinders and White [13]; and Stockwell and Reinders [14]);

3. Language educators need to create technology-mediated tasks that promote authentic interaction and meaningful collaboration (Gonzàlez-Lloret [3]; and Gonzàlez-Lloret and Ortega [15]);

4. Language educators need to create virtual language communities in which learners develop and maintain feelings of social connectedness (Bolliger and Inan [16]; Lomicka [4]). 
These recent studies all highlight the active and agentive role of language educators in establishing and sustaining interactive and connected virtual language learning environments through which they promote collaborative and meaningful interaction, and at the same time create a sustainable and authentic technology-mediated language learning environment.

\section{Methods}

\subsection{Setting and Participants}

The study was conducted at an English language program in Seoul Metropolitan University (SMU), a private South Korean university located in the Seoul Metropolitan Area. In an attempt to internationalize its campus and enhance students' competitiveness in the global market, the university mandates that all freshmen students must take two English conversation courses, "Basic English conversation" and "Advanced English conversation," over the course of two consecutive semesters. The required English conversation courses are taught by native English-speaking instructors and they meet once a week for two hours each, with the primary goal of providing freshmen students with opportunities to improve their oral language proficiency in English. These courses are largely devoted to speaking practice such as role plays, discussions and oral presentations. Each section of the required English conversation courses has approximately 20 students and the sections are categorized based on students' majors. All sections, regardless of major, use the same textbook and adhere to a shared curriculum.

The participants included seven EFL instructors who remotely taught an English conversation course required for all freshmen students in Spring 2020 (for participants' demographic characteristics, see Table 1$)$. The participants' mean age was $44.4(\mathrm{SD}=8.3)$. They had an average of 14.9 years $(\mathrm{SD}=5.5)$ of teaching experience in EFL contexts and 11 years $(\mathrm{SD}=5.2)$ of teaching experience in South Korean higher education. Despite the differences in participants' EFL teaching experiences, none of the participating instructors reported having received any formal training or education regarding online teaching prior to the COVID-19 pandemic. Two of seven participating instructors had the experience of teaching blended learning courses prior to the current outbreak, but their experience was limited to a one-time course or workshop. At the beginning of the semester, all seven participants received an emergency remote learning and teaching guide (a 20-page power point document) and an hour-long workshop provided by the Center for Teaching and Learning (CTL), affiliated with the university. The formal training provided by the university included instructions on using Webex, a video-conferencing tool provided by the university, and extensive training using a Moodle-based learning management system (LMS) that had traditionally been used at the university. Both the written guide and workshop provided instructors with basic information about how to set up courses for online delivery and how to utilize video-conferencing tools and online platforms for designing and delivering online courses. Additional teaching support provided online teaching and classroom management ideas from CTL, mostly on troubleshooting and increasing student engagement during classes on Webex.

Table 1. Participants' demographic characteristics.

\begin{tabular}{ccccc}
\hline Participants & Gender & $\begin{array}{c}\text { Teaching Experience } \\
\text { in EFL Context }\end{array}$ & $\begin{array}{c}\text { Teaching Experience in Korean } \\
\text { Higher Education }\end{array}$ & $\begin{array}{c}\text { Online Language } \\
\text { Teaching Experience }\end{array}$ \\
\hline Logan & Male & 12.5 years & 11.5 years & No \\
Elliott & Male & 12 years & 8 years & No \\
Caleb & Male & 23 years & 8 years & Yes \\
Matt & Male & 14 years & 10 years & Yes \\
Gina & Female & 7 years & 5 years & No \\
Lois & Female & 21 years & 21 years & No \\
Jake & Male & 14.5 years & 13.5 years & No \\
\hline
\end{tabular}




\subsection{Data Collection and Analysis}

The study was conducted using a case study methodology (Miles and Huberman [17]) to effectively conceptualize the challenges and strategies that were emerging during the first semester of fully transitioning to emergency remote learning. Data were collected during the course of the semester (February 2020-July 2020), using ethnographic fieldwork and qualitative interviews. Data collection included (a) administrator-level: bi-weekly faculty meeting minutes and reflection notes, the COVID-19 related university policy documents; (b) faculty-level: informal faculty meeting notes, email exchanges among participants and between participants and university administrators; (c) classroom-level: informal classroom observations and teaching materials and activity descriptions. In addition, researchers conducted in-depth qualitative interviews with all the participating faculty members and the program administrator to fully understand the experiences and decision-making processes in times of crisis.

Throughout the research period, researchers attended eight faculty meetings in which EFL instructors, including participants in the study, shared their difficulties and problems with online language teaching and discussed possible strategies to address these challenges. Each meeting lasted between $45 \mathrm{~min}$ and $1.5 \mathrm{~h}$. After each meeting, researchers wrote reflection notes to document informal conversations and non-verbal responses along with their initial thoughts. Six hours of informal classroom observation and follow-up discussions with participating instructors were conducted. Informal classroom observation was used because it is an effective way to observe teachers' teaching practices without giving them the impression of being evaluated (Downey et al. [18]). Because qualitative interview allows researchers to collect detailed accounts of participants' experiences (Rubin and Rubin [19]), we conducted qualitative interviews at the end of the semester with all the participating instructors to fully understand their experiences and perceptions regarding online language teaching in times of crisis. Each interview lasted from 1 to $2.5 \mathrm{~h}$, and all interviews were conducted in English. Interviews were audio-recorded and transcribed verbatim. In addition, 98 entries of online interaction data were collected and thematically analyzed. Grounded theory techniques (see Figure 1) were employed to interpret different sets of qualitative data gathered in this study, as well as to elicit recurring themes and patterns (Glaser and Strauss [20]; Strauss and Cobin [21]). Because these techniques aim to consolidate different data sets into matrices in order to generate recurring themes and patterns, all the qualitative data were first coded line-by-line by using action-oriented descriptors (open coding). This also involved examining data to identify the properties of the themes and their interrelationships such as similarities and differences in participating instructors' narratives of their experiences. Line-by-line coding was followed by two selective coding categories: (a) all the data were sorted chronologically in order to understand the overall experience of participating instructors, and (b) all the data were sorted and coded thematically in order to identify core themes and categories to create a story line (Strauss and Cobin [21]). Selected coding condensed the data set, and allowed a comparison of participating instructors' experiences, challenges and strategies across different data sources (Charmaz, [22]). Because this study aimed to conceptualize the challenges and strategies that were emerging in the crisis-prompted online language learning and teaching context, we also examined and organized the data both chronologically and thematically. 


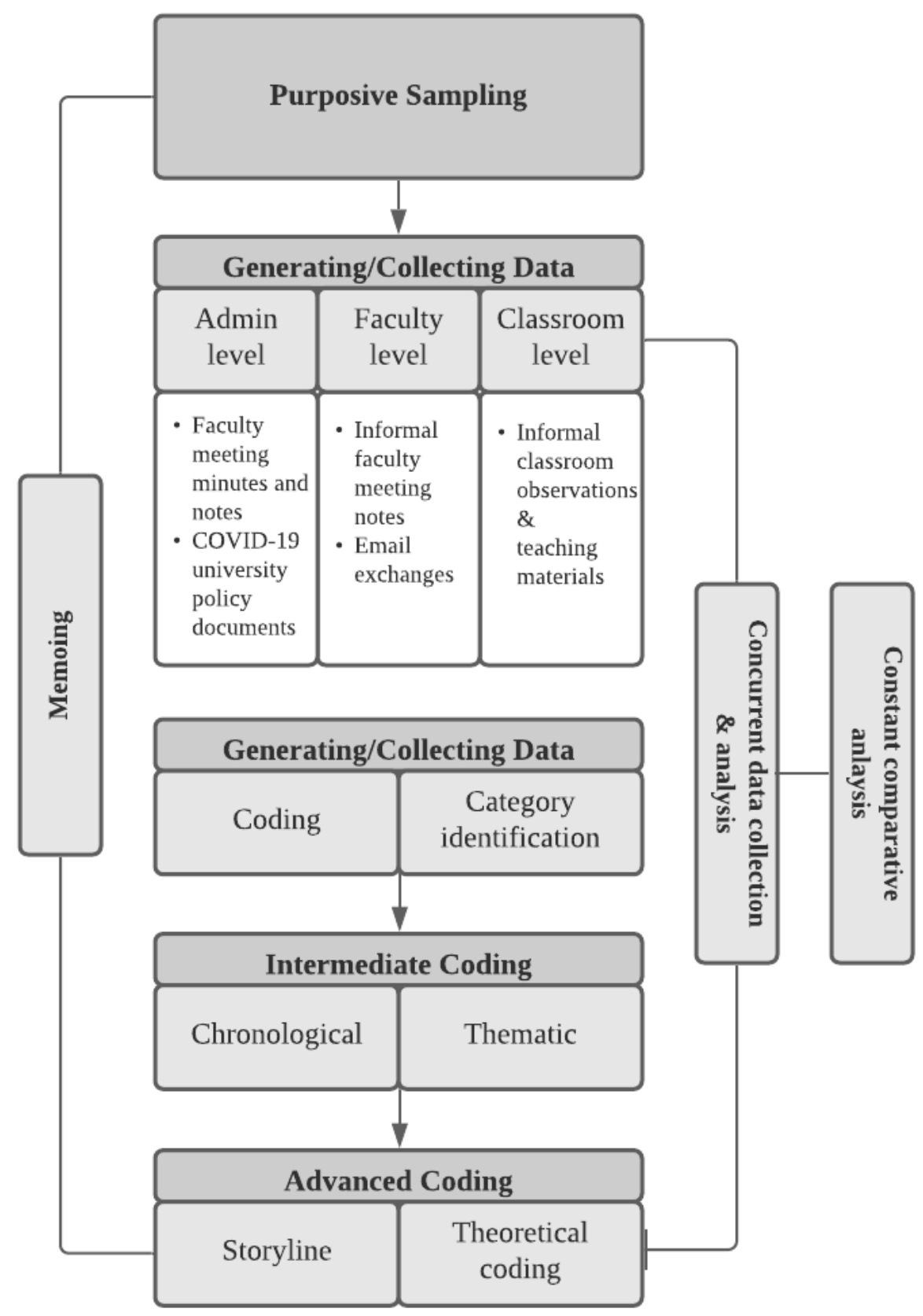

Figure 1. Data collection and analysis process.

\section{Results}

\subsection{Emergency Remote Language Teaching: EFL Instructors' Challenges}

The COVID-19 pandemic has impacted the entire South Korean educational system, and has led to nationwide school closures, encompassing all sectors of the educational spectrum, from kindergarten through higher education. In response to the COVID-19 pandemic, most universities and schools in South Korea modified their Spring 2020 schedules and postponed the start of the school year. Alongside many South Korean universities, SMU changed its academic calendar and modes of instruction multiple times between February and May 2020 (see Table 2). 
Table 2. Timeline of major events and changes during Spring 2020.

\begin{tabular}{|c|c|c|c|}
\hline Date & COVID-19 Outbreak & S. Korean Government & Seoul Metropolitan University \\
\hline 6 February 2020 & $\begin{array}{l}\text { Total confirmed cases: } 23 \\
\text { Daily new cases: } 4\end{array}$ & $\begin{array}{l}\text { Provided COVID-19 infection } \\
\text { prevention and control guide. }\end{array}$ & $\begin{array}{l}\text { Released first announcement regarding } \\
\text { postponing the start of semester from } \\
2 \text { March } 2020 \text { to } 16 \text { March } 2020 .\end{array}$ \\
\hline 4 March 2020 & $\begin{array}{l}\text { Total confirmed cases: } 5328 \\
\text { Daily new cases: } 516\end{array}$ & $\begin{array}{l}\text { Provided social distancing } \\
\text { recommendations. }\end{array}$ & $\begin{array}{l}\text { Released second announcement regarding } \\
\text { postponing the start of semester from } \\
16 \text { March } 2020 \text { to } 30 \text { March } 2020 .\end{array}$ \\
\hline 24 March 2020 & $\begin{array}{l}\text { Total confirmed cases: } 9037 \\
\text { Daily new cases: } 76\end{array}$ & $\begin{array}{l}\text { Provided social distancing } \\
\text { recommendations. }\end{array}$ & $\begin{array}{l}\text { Announced that all the classes should be } \\
\text { held via synchronous online sessions on } \\
\text { a temporary basis until further notice. } \\
\text { Provided tutorial information about } \\
\text { remote education. }\end{array}$ \\
\hline 31 May 2020 & $\begin{array}{l}\text { Total confirmed cases: } \\
\text { 11,468Daily new cases: } 27 \\
\text { Total confirmed cases on } \\
\text { campus: } 2\end{array}$ & $\begin{array}{l}\text { Recommendation to social } \\
\text { distance in daily life } \\
\text { (saenghwal sog geolidugi). }\end{array}$ & $\begin{array}{l}\text { Announced that all the classes would be } \\
\text { held remotely throughout the } \\
\text { entire semester. }\end{array}$ \\
\hline
\end{tabular}

At the beginning of February 2020, SMU first postponed the start of the semester from 2 March to 16 March 2020. Since South Korea entered a new phase of local transmission beginning on 18 February 2020, SMU delayed the opening of its semester until 30 March 2020, and required all classes to be held remotely on a temporary basis until further notice. As nationwide social distancing requirements continued and two then-current SMU students tested positive for COVID-19, SMU announced on 31 May 2020 that all the classes would be held remotely for the remainder of the semester.

Faced with this constantly changing scenario and attendant uncertainties, participants were struggling to adapt their instruction to online formats on short notice and to find ways to increase their skills and familiarity with educational technologies to successfully deliver online language teaching. Through interviews and faculty meetings, participating instructors variously described their experiences in teaching during Spring 2020 as "walking through the fog", "very challenging", "hard to navigate through" and "a struggle to survive". Even though SMU and other inter- and intra-national organizations provided various resources for virtual instruction and online learning, all the participating instructors reported that they believed that there was often a lack of adequate and timely support and guidance throughout the semester. As previous studies have pointed out, transitioning to teaching fully online requires professional training for educators who need to develop new approaches to education and adopt new competencies in online teaching environments (Adnan [23]; Berge [11]; Gacs et al. [24]; and Hampel and Stickler [7]). During this sudden educational disruption, instructors, however, were asked to quickly switch to an online course delivery without receiving sufficient training or support for how to establish onlineready classrooms and create interactive online learning environments using digital devices and online platforms.

As participating instructors navigated through constantly changing circumstances and demands throughout the semester, they experienced four phases of professional development: (a) a preparation phase (prior to the start of the semester), (b) an exploration phase (week 1-week 4), (c) an adjustment phase (week 5-week 9), and (d) a mastery phase (week 10-week 15). As shown in Table 3, participating instructors were given a week to make their transition from face-to-face classrooms to distance and online learning environments. All the participating instructors pointed out that it was challenging to redesign their courses without having completely clear directions regarding the form of instruction and instructional guidance, such as how long they would be teaching remotely and what kinds of digital platforms would be available for use in their classrooms. 
Table 3. Different challenges emerged during Spring 2020.

\begin{tabular}{|c|c|c|}
\hline Phase & Major Challenges & Major Tasks to Be Completed \\
\hline $\begin{array}{l}\text { Preparation Phase } \\
(24-29 \text { March 2020) }\end{array}$ & $\begin{array}{l}\text { - Uncertainty over form of instruction } \\
\text { - Lack of training and resources for } \\
\text { online teaching }\end{array}$ & $\begin{array}{l}\text { - Learn how to use digital tools and online } \\
\text { platforms, including Webex, which was } \\
\text { recommended for use by the university } \\
\text { Redesign face-to-face course for } \\
\text { an online format }\end{array}$ \\
\hline $\begin{array}{c}\text { Exploration Phase } \\
\text { (30 March-26 April 2020) }\end{array}$ & $\begin{array}{l}\text { - Technology-related issues such as } \\
\text { software installation and troubleshooting, } \\
\text { internet inaccessibility and poor } \\
\text { technical skills } \\
\text { - } \quad \text { Students' poor technical skills }\end{array}$ & $\begin{array}{l}\text { - Share technology-related issues and discuss } \\
\text { practical solutions } \\
\text { - Provide students technological support } \\
\text { and guidance }\end{array}$ \\
\hline $\begin{array}{c}\text { Adjustment Phase } \\
\text { (27 April-31 May 2020) }\end{array}$ & $\begin{array}{l}\text { - Insufficient interaction among students } \\
\text { and between students and instructors } \\
\text { - Students' perceived feelings of } \\
\text { being disconnected }\end{array}$ & 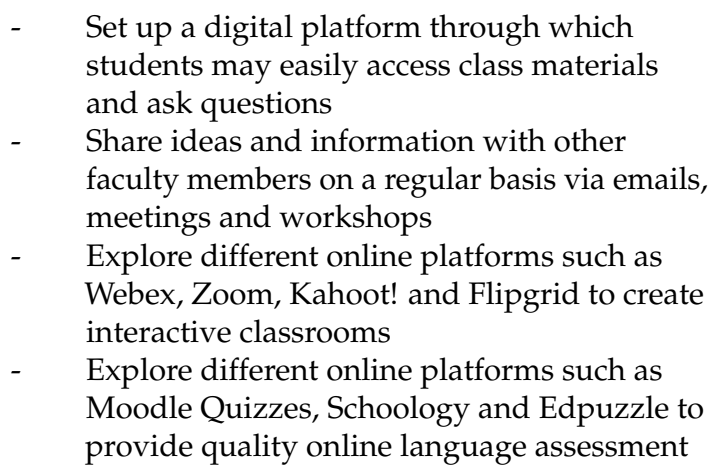 \\
\hline $\begin{array}{l}\text { Mastery Phase } \\
\text { (1-10 June 2020) }\end{array}$ & $\begin{array}{l}\text { Insufficient opportunities to enable } \\
\text { students to engage in collaborative } \\
\text { interaction and sustainable language } \\
\text { development and use }\end{array}$ & $\begin{array}{l}\text { - Create and maintain virtual language } \\
\text { learning communities by using } \\
\text { online platforms }\end{array}$ \\
\hline
\end{tabular}

As the semester began and instructors and their students began to hold synchronous sessions, participating instructors moved into the second phase in which they experienced various technology-related issues such as software installation and troubleshooting and internet inaccessibility and poor technical skills, along with students' poor connectivity issues and limited technical skills. In order to solve these issues, they actively shared emerging challenges daily via emails, online messengers and the Google spreadsheet, and collaboratively worked to create practical solutions that could address these technologyrelated issues. The following email sent by Jake on 4 April illustrates how actively and collaboratively these EFL instructors navigated through uncertain times:

"If anyone is interested, I will plan on being online with Webex today at 6 p.m. I am interested in sharing some of my ideas and hearing from others as to how they plan on using a video conferencing tool for their online classes next week as there were a number of concerns in some of the comments from the Google feedback sheet. Many said this week went well, barring some technical issues, but moving forward some were not sure how to approach this coming week. I hope you are able to join and share some of your ideas or listen to the ideas of others." (Email written by Jake, 4 April 2020)

In addition, they often consulted with university administrators to obtain needed support and services to ensure better connectivity with students. Most of the initial issues addressed in the first month were gradually but quickly resolved, and participating instructors no longer experienced major technology-related issues after the fourth week.

In the third phase, participating instructors reported insufficient student interaction and lack of participation as the two major challenges they faced in their online language classrooms. They pointed out that students were less willing to participate in online interaction due to their lack of motivation and reported feelings of being disconnected (c.f., Bolliger and Inan [16]; Lomicka [4]). In order to arouse students' motivation and increase 
their participation in online language learning, participating teachers actively explored different online platforms such as Webex, Zoom, Kahoot! and Flipgrid, and searched for information regarding available technologies and resources to create interactive and engaging language learning environments. Additionally, they often shared information about online platforms and their effectiveness among themselves and with their colleagues who were also teaching English at a tertiary educational institution across the world. All the participating instructors stated that joining in this self-generated professional community helped them further their thought processes and professional development (c.f., Adnan [23]; Paesani [25]).

In the last phase, they also worked on creating and maintaining virtual language learning communities as an attempt to facilitate a collaborative interaction among students and to foster their sustainable language learning and use. Compared to face-to-face language learning classrooms, participating instructors stated that they felt that their online classrooms were more teacher-centered, with limited opportunities for a collaborative interaction among students. They all stated that their experience of teaching online for the previous nine weeks and their intense investment in adopting new competencies in online teaching enabled them to navigate their way through different digital tools and online platforms to design and create their own online classrooms. With newly acquired skills and knowledge about educational technologies, all the participating instructors in this phase worked on establishing virtual language learning communities for their students, which they said they believe could enhance students' feelings of social connectedness and increase their self-efficacy beliefs.

\subsection{Emergency Remote Language Teaching: EFL Instructors' Strategies}

While a meaningful and collaborative interaction is central to language learning classrooms (Gass [26]; Swain and Watanabe [27]), it is never easy to promote a meaningful language learning experience in online learning environments. Indeed, all the instructors in the present study pointed out that the reported lesser amount of interactivity and collaborative effort was one of the major challenges they encountered during Spring 2020, compared to traditional face-to-face language learning classrooms. As one instructor described:

"I have been teaching English conversation courses for more than fifteen years in Korea. And I know exactly what to do to make my students talk to each other and work together. But teaching English online was really different from teaching offline. I taught freshmen who hadn't met each other in person. And most of them hadn't even been on a campus because of the coronavirus. They were shy and didn't want to make any mistakes or say something that could come across as weird... At the beginning of the semester, I had a really hard time to make students say something to each other, even simple things like 'hello' and 'how are you?'." (Louis, an individual interview)

Similar accounts can be found in interviews and faculty meetings where participating instructors found it challenging to stimulate students to engage in online conversations. In traditional face-to-face classrooms, all the participating instructors encouraged their students to constantly engage in pair work, group discussions and presentations, and to work to facilitate student interactions and collaborations. As the above interview excerpt illustrates, the instructors realized that the strategies and techniques effectively used in traditional face-to-face classrooms were not transferred to technology-mediated language learning classrooms. Therefore, they needed to develop new strategies for motivating students to participate in class interactions by creating and maintaining a safe space through which students could comfortably and confidently engage in meaningful interactions. The major strategies they developed and used included (a) enhancing the feeling of social connectedness by encouraging students to be virtually present and accessible, and (b) providing students with goal-directed and sustainable technology-mediated tasks. 
4.2.1. Enhance the Feeling of Social Connectedness by Encouraging Everyone to Be Virtually Present and Accessible

In order to encourage students' collaborative interaction and active participation, all the participating instructors stressed the importance of increasing students' feelings of connectedness and belongingness. Their arguments resonated with recent research findings, which have identified social presence as key to enhancing students' degrees of participation in and satisfaction with online learning (Gunawardena et al. [28]; Gunawardena and Zittle [29]; Hostetter and Busch [30]; Richardson and Swan [31]). Social presence refers to an individual's perceived sense of online community and salience of proximity and intimacy that is experienced with another person in a technology-mediated communication setting (Short et al. [32]). All the participating teachers pointed out that a higher level of social presence significantly increased students' interaction with and participation in online language classrooms, especially EFL online classrooms, in which language learners may experience apprehension about the effectiveness of their various means of communication, fear of receiving a negative evaluation and test anxiety. The following is the list of strategies participating teachers used to develop students' feelings of connectedness in online language learning environments:

1. Encourage students to turn on the webcam and be virtually present in online learning environments;

2. Encourage students to show their virtual presence by using non-verbal communication cues such as physical gestures: "Please give the thumbs up sign if you understood the question", and "Please form a circle with your thumb and forefinger if you are ready for the next activity";

3. Ask students to collaboratively write a summary of their group work via Google Docs while engaging in group discussions and projects;

4. Be visible and virtually accessible to students who might need extra support or intervention;

5. Sympathize with students' feelings of being isolated or uneasy in remote settings.

Since online language learning classrooms were new to their students, all the participating instructors emphasized the importance of staying visible and being virtually accessible to their students. Some specific strategies used by the participating instructors include turning on the webcam during the entire class, setting up a group chat via KakaoTalk (a multifaceted messaging application widely used in South Korea) to easily communicate with students during non-class hours, and creating video-recorded class announcements or instructions. As one instructor reported:

"I really opened up to them and said to them, 'If you have any questions, please [feel free to contact me anytime, day or night]'. [At first] they felt like they were bothering me. They were like 'sorry to be bothering you during the weekend'. And I was like 'you are not a bother. I am here. I am here 24/7 ... I don't mind getting a KakaoTalk message at 3 a.m. ... I am here to help you. We will work together and we all will have a great semester' ... . I spent most of my time trying to motivate them so that they can feel comfortable and express themselves ... At the end of the semester, many students said 'thank you because I felt more confident online and more confident talking online.'" (Jake, an individual interview)

Jake also stated that being visible and present was essential for creating a virtual language learning environment in which students developed a sense of social connectedness and built a mutual understanding of expectations and goals (c.f., Meskill and Anthony [31]). In addition, four participating instructors highlighted the need for understanding and sympathizing with students' uneasiness about online learning and virtual communication so that they could better assist students in developing feelings of connectedness. As one instructor noted:

"They said they enjoyed my class and I had a lot of fun even though it was online. They were like me: a lot of students were like a die-hard offline fan. [I told them] 'I am an 
offline person. Me, too. I can't stand this'. And then we kind of laughed about it together. They were like 'so we can't have a class at coffeeshops or somewhere' [laughing]. [I told them] 'Let's make sure to be safe. I want it to be offline more than any of you guys. Trust me, but let's just be safe.'" (Caleb, an individual interview)

Caleb and other participating instructors explained that sharing their uneasiness and discomfort about online teaching helped them to foster a sense of mutual understanding and connection in their online classrooms. They also claimed that sharing their personal stories and experiences with students enabled their students to be more open and willing to participate in meaningful interactions. Their accounts aligned with recent arguments concerning the power of acknowledging one's imperfections and sharing personalized stories with students (see Lomicka [4] for more discussion).

\subsubsection{Provide Students Sustainable and Authentic Technology-Mediated Tasks}

Recent studies on online language learning have emphasized the importance of designing and providing meaningful tasks in order to raise students' motivation and sense of autonomy (e.g., Baralt and Morcillo Gómez [33]; González-Lloret [34]). González-Lloret and Ortega [14], for example, identified effective technology-mediated tasks for language teaching, as follows: (a) focus on meaning, (b) goal-oriented with a communicative purpose, (c) related to students' needs and real-world interests, (d) involved in experiential learning. Similarly, designing appropriate tasks had been the most discussed issue among participating instructors throughout the semester. As they experienced the lack of students' engagement and motivation in online language learning environments, they realized the importance of providing students with goal-directed, sustainable and authentic tasks by which students could autonomously engage in a meaningful and collaborative interaction. Thus, in the middle of the semester, all the participating instructors changed the nature of language learning tasks used in their online classrooms. They characterized effective technology-mediated language learning tasks as follows:

1. Provide students with more goal-oriented tasks that required them to use target language features for task accomplishment;

2. Provide students with more sustainable tasks that could be accomplished through a series of practical activities;

3. Provide students with more authentic tasks that are relevant to their daily lives.

Elliot, for example, asked his students to create a weekly, two-minute personal narrative in which they share stories or opinions using target language features. These narratives would be video-recorded and uploaded online so that students and instructor could provide one another with comments and feedback. He also gave students individual feedback on both form- and content-related issues. He found that this type of technology-mediated task not only enhanced students' interaction but also increased their level of satisfaction:

"Rather than having a big speaking exam at the end of the semester, I decided to give students weekly assignments where students can interact and I can check their progress. Starting from Week 8, all the students need to create and upload their weekly assignment ... I got so many comments from students, saying, 'When I first started to do the Flipgrid every week, I couldn't stand it. I hated it.' In the middle of the semester, [students told me] 'Well, it's not too bad. I know what I need to do for the homework and it's nice to see my progress.' And then by the end, [students told me] 'I don't feel scared. If you ask me to speak in English, I can do it. I don't feel scared anymore'." (Elliot, an individual interview)

Others redesigned their language learning tasks to make them more sustainable and authentic, such as when students were asked to engage in a series of connected practical activities and interject their own personal experiences or stories. The following is an activity that an instructor named Gina used in her conversation class:

As outlined in Table 4, Gina gave her students a series of language tasks by which the students could individually and later collaboratively use target language features and 
engage in authentic interaction. All the participating instructors reported that goal-oriented, sustainable and authentic technology-mediated language learning tasks not only enhanced students' degree of engagement but also increased their collaborative interactions.

Table 4. An example of sustainable and authentic technology-mediated language learning tasks.

\begin{tabular}{lll}
\hline \multicolumn{1}{c}{ Week } & & \multicolumn{1}{c}{ Activities } \\
Week 10-11 & - & $\begin{array}{l}\text { Learn about an everyday hero in our society } \\
\text { Learn target language forms and complete short individual assignments } \\
\text { Receive individual feedback }\end{array}$ \\
Week 12 & - & $\begin{array}{l}\text { Individual work: Create a } 1 \text { min video about your own hero, using target } \\
\text { language forms } \\
\text { Receive feedback from instructor and peers }\end{array}$ \\
\hline Week 13 & - & $\begin{array}{l}\text { Pair work: Create a } 2 \text { min video featuring a mock interview with your } \\
\text { own hero using target forms } \\
\text { Receive feedback from instructor and peers }\end{array}$ \\
& - & Group work: Create a 3 min video introducing everyday heroes \\
& - & $\begin{array}{l}\text { in our society } \\
\text { Receive feedback from instructor and peers }\end{array}$ \\
\hline
\end{tabular}

\section{Discussion and Conclusions}

"There were some technical issues. In the beginning, there was some clashing, which was very frustrating. And I felt that the online learning format did not provide enough support that we needed. But it evolved and I embraced it. And I am grateful for the experience." (Jake, an individual interview)

"This semester was very different and the real challenge was to find right tools and tasks to promote interaction ... I had been working closely with other faculty members to navigate through this semester full of challenges and uncertainties ... I do feel like it was a successful semester and I learned a lot." (Matt, an individual interview)

As the above interview excerpts from two participating instructors illustrate, the COVID-19 pandemic has brought with it a new set of challenges for language educators to overcome, and at the same time opportunities for them to rethink instruction towards more sustainable and authentic language learning (c.f., Moser et al. [35]). As the findings of this paper reveal, it is important to think about how to effectively provide language educators with sustainable training and professional development so that they can foster students' language learning in the post-COVID 19 era. Findings suggest three pedagogical implications concerning technology-mediated, sustainable teaching.

First, it is important to provide language educators with the adequate training and experience necessary to effectively use interactive digital platforms and tools to enhance students' active engagement in a meaningful and collaborative interaction online. While all the participating instructors used Webex and a Moodle-based learning management system as the main platform for instruction, they all found the use of interactive digital platforms as a supplementary teaching tool effective in increasing students' interaction and fostering their sustainable language learning and use. They, for example, used Padlet, Flipgrid and Google Docs for collaborative activities, and Kahoot!, Quizzes, Edpuzzle, and Genially for mini quizzes and tests. They also actively used mobile instant messaging applications such as KakaoTalk and Line to increase both student-teacher and student-student interaction. They all stated that these interactive digital platforms create an immediate but private space where students can autonomously engage in meaningful interaction. They, however, stated that it was challenging for them to effectively use technology and digital tools with little experience and training. As Koehler et al. [36] point out, technology in language learning and teaching is "not an add-on but rather integral to teaching performance" (151). 
That is, language educators need to have adequate training and sufficient opportunities to become familiar with different digital tools, and develop their skills to integrate them into language teaching (e.g., Jiang et al. [37]; Liu and Kleinsasser [38]; Lomnicka [4]; Paesani [23]). In addition, findings showed that unlike a well-planned online learning and teaching environment, the hastily assembled online language learning environment caused various technology-related issues at the beginning of the semester, including limited access to technology infrastructure and connectivity issues. It is noteworthy that in this initial phase, participating instructors in their first phase conducted a troubleshooting session among themselves nearly every day for the first two weeks of the semester. Given that many educators were not accustomed to online teaching and educational technologies prior to the current COVID-19 pandemic, it is necessary to provide them with more tailored technical support (c.f., Langford and Damaşa [39]).

Second, it may be necessary to promote the concept of collective responsibility among language educators in order to encourage them to be part of teachers' sustained professional conversation. Teachers' collective responsibility was central to their collaborative professional development. As recent studies have highlighted, teachers' collective responsibility for student learning can be positively and significantly related to teachers' willingness to hold themselves accountable for collaborative and sustainable professional development, which can enhance students' academic success (c.f., Huang et al. [40]; Laferrière et al. [41]; Maclntyre et al. [42]; Vo and Nguyen [43]; Zonoubi et al. [44]). In more practical terms, since many language educators are struggling to adjust their teaching practices during this worldwide health crisis, building professional communities either online or face-to-face would be an effective way for them to work together to navigate their way through this constantly changing set of circumstances. In addition, promoting collective responsibility and cooperation among language educators can create school culture that can foster students' sustainable language learning and development.

Third, it is important to promote self-generated communities of practice where teachers can collaboratively work with others and participate in continuous professional development. In this study, all the participating instructors found their self-generated professional community extremely helpful, as they worked collaboratively to reflect on their online teaching experiences and devise practical solutions and strategies to make their online classes more interactive and engaging. As recent studies have highlighted, promoting selfgenerated communities of practice can not only enable teachers to become more agentive but also empower teachers in a sustainable and lifelong professional development perspective (c.f., Katsarou and Tsafos [45]; James and Augustin [46]). Because the study examined the case of EFL instructors in a university setting, the findings might not be accurately portraying the needs and experiences of educators and administrators in different contexts. The study, however, provides some practical suggestions and strategies that educators and administrators at all levels across the world might consider while making a rapid transition to online learning. As Daniela et al. [47] point out, it is important for school administrators and policymakers to understand the struggles and needs that educators are facing in times of crisis, and provide them with effective technical and instructional assistance that enable them to redesign curricula and pedagogical practices to develop sustainable education.

Author Contributions: Conceptualization, S.C. and L.C.; formal analysis, S.C. and L.C.; investigation, S.C. and L.C.; methodology, S.C. and L.C.; writing-original draft, S.C. and L.C.; writing-review \& editing, S.C. and L.C. All authors have read and agreed to the published version of the manuscript.

Funding: This work was supported by 2021 Hongik University Research Fund.

Institutional Review Board Statement: Not applicable.

Informed Consent Statement: Informed consent was obtained from all subjects involved in the study.

Data Availability Statement: The data presented in this study are available on request from the corresponding author. 
Conflicts of Interest: The authors declare no conflict of interest.

\section{References}

1. Bozkurt, A.; Sharma, R.C. Emergency remote teaching in a time of global crisis due to CoronaVirus pandemic. Asian J. Distance Educ. 2020, 15, i-vi.

2. OECD. Education Responses to COVID-19: Embracing Digital Learning and Online Collaboration. Available online: https: / / www.oecd.org/coronavirus/policy-responses/education-responses-to-covid-19-embracing-digital-learning-andonline-collaboration-d75eb0e8 (accessed on 10 March 2021).

3. González-Lloret, M. Collaborative tasks for online language teaching. Foreign Lang. Ann. 2020, 53, 260-269. [CrossRef]

4. Lomicka, L. Creating and sustaining virtual language communities. Foreign Lang. Ann. 2020, 53, 306-313. [CrossRef]

5. Baran, E.; Correia, A.; Thompson, A. Transforming online teaching practice: Critical analysis of the literature on the roles and competencies of online teachers. Distance Educ. 2011, 32, 421-439. [CrossRef]

6. Natriello, G. Modest changes, revolutionary possibilities: Distance learning and the future of education. Teach. Coll. Rec. 2005, 107, 1885-1904. [CrossRef]

7. Hampel, R.; Stickler, U. New skills for new classrooms. Training tutors to teach languages online. Comput. Assist. Lang. Learn. 2005, 18, 311-326. [CrossRef]

8. Lamy, M.; Hampel, R. Online Communication in Language Learning and Teaching; Palgrave Macmillan: New York, NY, USA, 2007.

9. Russell, V.; Murphy-Judy, K. Teaching Language Online: A Guide to Designing, Developing, and Delivering Online, Blended, and Flipped Language Courses; Routledge: New York, NY, USA, 2020.

10. Sun, S. Learner perspectives on fully online language learning. Distance Educ. 2014, 35, 18-42. [CrossRef]

11. Bennett, S.; Lockyer, L.; Agostinho, S. Towards sustainable technology-enhanced innovation in higher education: Advancing learning design by understanding and supporting teacher design practice. Br. J. Educ. Technol. 2018, 49, 1014-1026. [CrossRef]

12. Berge, Z. Changing instructor's roles in virtual worlds. Q. Rev. Distance Educ. 2009, 9, 407-415.

13. Reinders, H.; White, C. 20 years of autonomy and technology: How far have we come and where to next? Lang. Learn. Technol. 2016, 20, 143-154.

14. Stockwell, G.; Reinders, H. Technology, motivation and autonomy, and teacher psychology in language learning: Exploring the myths and possibilities. Annu. Rev. Appl. Linguist. 2019, 29, 40-51. [CrossRef]

15. González-Lloret, M.; Ortega, L. Towards technology-mediated TBLT: An introduction. In Technology-Mediated TBLT: Researching Technology and Tasks; González-Lloret, M., Ortega, L., Eds.; John Benjamins Publishing Company: Amsterdam, The Netherland; Philadelphia, PA, USA, 2014; pp. 1-22.

16. Bollinger, D.C.; Inna, F.A. Development and validation of the online student connectedness survey (OSCS). Int. Rev. Res. Open Distance Learn. 2012, 13, 41-65. [CrossRef]

17. Miles, M.B.; Huberman, A.M. Qualitative Data Analysis: An Expanded Sourcebook, 2nd ed.; Sage: Thousand Oaks, CA, USA, 1994.

18. Downey, C.; Steffy, B.; English, F.; Frase, L.; Poston, W. The Three-Minute Classroom Walk-Through: Changing School Supervisory Practice One Teacher at a Time; Corwin Press: Thousand Oaks, CA, USA, 2018.

19. Rubin, H.J.; Rubin, I.S. Qualitative Interviewing: The Art of Hearing Data, 2nd ed.; Sage: Thousand Oaks, CA, USA, 2005.

20. Glaser, B.; Strauss, A. The Discovery of Grounded Theory: Strategies for Qualitative Research; Sociology Press: Mill Valley, CA, USA, 1967.

21. Strauss, A.; Corbin, J.M. Basics of Qualitative Research: Grounded Theory Procedures and Techniques; Sage: New York, NY, USA, 1990.

22. Charmaz, K. Grounded theory. In Contemporary Field Research: Perspectives and Formulations; Emerson, R.M., Ed.; Waveland: Prospect Heights, NY, USA, 2001; pp. 335-352.

23. Adnan, M. Professional development in the transition to online teaching: The voice of entrant online instructors. ReCALL 2018, 30, 88-111. [CrossRef]

24. Gacs, A.; Goertler, S.; Spasova, S. Planned online language education versus crisis-prompted online language teaching: Lessons for the future. Foreign Lang. Ann. 2020, 53, 380-392. [CrossRef]

25. Paesani, K. Teacher professional development and online instruction: Cultivating coherence and sustainability. Foreign Lang. Ann. 2020, 53, 292-297. [CrossRef]

26. Gass, S. Input, Interaction, and the Second Language Learner; Lawrence Erlbaum: Hillsdale, NJ, USA, 1997.

27. Swain, M.; Watanabe, Y. Languaging: Collaborative dialogue as a source of second language learning. In The Encyclopedia of Applied Linguistics; Chapelle, C.A., Ed.; Blackwell Publishing Ltd.: Oxford, UK, 2014; pp. 18-42.

28. Gunawardena, C.N.; Lowe, C.A.; Anderson, T. Analysis of a global online debate and the development of an interaction analysis model for examining social construction of knowledge in computer conference. J. Educ. Comput. Res. 1997, 17, 397-431. [CrossRef]

29. Gunawardena, C.N.; Zittle, F.J. Social presence as a predictor of satisfaction within a computer-mediated conferencing environment. Am. J. Distance Educ. 1997, 11, 8-26. [CrossRef]

30. Hostetter, C.; Busch, M. Measuring up online: The relationship between social presence and student learning satisfaction. J. Scholarsh. Teach. Learn. 2006, 6, 1-12.

31. Richardson, J.C.; Swan, K. Examining social presence in online courses in relation to students' perceived learning and satisfaction. J. Asynchronous Learn. Netw. 2003, 7, 68-88. [CrossRef]

32. Short, J.; Williams, E.; Christie, B. The Social Psychology of Telecommunications; John Wiley: London, UK, 1976. 
33. Baralt, M.; Morcillo Gómez, J. Task-based language teaching online: A guide for teachers. Lang. Learn. Technol. 2017, 21, 28-43.

34. González-Lloret, M. A Practical Guide to Integrating Technology into Task-Based Language Teaching; Georgetown University Press: Washinton, DC, USA, 2016.

35. Moser, K.M.; Wei, T.; Brenner, D. Remote teaching during COVID 19: Implications from a national survey of language educators. System 2021, 97, 1-102431. [CrossRef]

36. Koehler, M.; Mishra, P.; Bouck, E.; DDeSchryyer, M.; Kereluik, K.; Shin, T.; Wolf, L. Deep-play: Developing TPACK for 21st century teachers. Int. J. Learn. Technol. 2011, 6, 146-163. [CrossRef]

37. Jiang, L.; Zang, N.; Zhou, N.; Cao, H. English teachers' intention to use flipped teaching: Interrelationships with needs satisfaction, motivation, self-efficacy, belief, and support. Comput. Assist. Lang. Learn. 2021, 1-30. [CrossRef]

38. Liu, M.; Kleinsasser, R.C. Exploring EFL teachers' CALL knowledge and competencies: In-service program perspectives. Lang. Learn. Technol. 2015, 19, 119-138.

39. Langford, M.; Damasa, C. Online Teaching in the Time of COVID-19: Academics' Experiences in Norway. Available online: https:/ / khrono.no/ files/2020/04/16/Report-University-Teachers-15-April-2020.pdf (accessed on 10 March 2021).

40. Huang, F.; Teo, T.; Guo, J. Understanding English teachers' non-volitional use of online teaching during the COVID-19 pandemic: A Chinese case. System 2021, 101, 1-102574. [CrossRef]

41. Laferrière, T.; Lamon, M.; Chan, C.K.K. Emerging e-trends and models in teacher education and professional development. Teach. Educ. 2006, 17, 75-90. [CrossRef]

42. Maclntyre, P.D.; Gregersen, T.; Mercer, S. Language teachers' coping strategies during the COVID-19 conversion to online teaching: Correlations with stress, wellbeing and negative emotions. System 2020, 94, 1-102352. [CrossRef]

43. Vo, L.T.; Nguyen, H.T.M. Critical friends group for EFL teacher professional development. ELT J. 2010, 64, 205-213. [CrossRef]

44. Zonoubi, R.; Rasekh, A.E.; Tavakoli, M. EFL teacher self-efficacy development in professional learning communities. System 2017, 66, 1-12. [CrossRef]

45. Katsarou, E.; Tsafos, V. Student-teacher as researchers: Towards a professional development orientation in teacher education: Possibilities and limitations in the Greek University. Educ. Action Res. 2013, 21, 532-548. [CrossRef]

46. James, F.; Augustin, D.S. Improving teachers' pedagogical and instructional practice through action research: Potential and problems. Educ. Action Res. 2018, 26, 333-348. [CrossRef]

47. Daniela, L.; Visvizi, A.; Gutiérrez-Braojos, C.; Lytras Miltiadis, D. Sustainable higher education and technology-enhanced learning (TEL). Sustainability 2018, 10, 3883. [CrossRef] 